\title{
Identifying and Addressing the Challenges of Logic and Memory Integration
}

\author{
Craig MITCHELL*
}

ロジック+メモリのパッケージ統合：技術的およびロジスティックな課題と挑戦

*Tessera, Inc. (3099 Orchard Drive, San Jose, CA 95134, USA)

\begin{abstract}
概要 携帯電子機器はその小型制約の中, 要求される機能がますます增加している。半導体業界では2Dから3Dへのパッ ケージが進んでいる。携帯電話などで最む広がりを見せているのが1つのCSPの中にフラッシュやSRAMなどのメモリーチッ プ同士を垂直方向に積み重䄈るダイスタックタイプのパッケージである。しかし，異種のデバイス，たとえばロジックとメモ リーの積み重ねには課題が多い。本稿はそれらの技術的なかつロジスティックな各課題について説明する。そして, それらの 課題に対する 1 つの回答としてパッケージそのあのの積み重ねを可能にするCSPを紹介する。またそこで使用されるサブスト レートおよびパッケージ，積み重权工程についても触れる。
\end{abstract}

\section{Introduction}

Delivering enhanced features and functions in smaller electronic products has presented the electronics industry a range of design and assembly challenges. Handset manufacturers in particular are driving toward lower cost, smaller size, and reduced component count in products that offer greater functionality and ultimately an enhanced user experience ${ }^{1)}$. To develop these next-generation "convergent" products, designers are forced to weigh a broad range of tradeoffs, including how to deliver desired features and functions without sacrificing size, cost, time-to-market or supply chain efficiencies.

The semiconductor industry has been exploring three dimensional packaging to address many of the integration challenges associated with developing higher functionality products in smaller form factors. Mobile phones represent the most significant application for 3D packages today-other applications include portable consumer products such as digital camcorders and cameras ${ }^{2}$. Currently, the most widespread 3D packages utilize die stacking technologies within a single chip-scale package (CSP). These die stacked components are being broadly adopted for combining high yielding memory devices (such as Flash+SRAM) that have similar size and wiring requirements, low power dissipation and established wafer supply relationships.

\section{Defining the Challenges}

As handset manufacturers drive toward greater system-level integration, the industry is exploring the feasibility of stacking mixed device types, such as logic + memory, within a single package. While die stacking continues to be an effective solution for stacking similar device types, some key issues emerge with dielevel integration of mixed device types (Figure 1).

Die Supplier Management: Placing chips from multiple silicon vendors into a single integrated package introduces several complex business and supply chain management problems ${ }^{3)}$. When an OEM design demands a package incorporating chips from multiple silicon vendors, these vendors must create business relationships allowing packaging of their chips with chips from other suppliers. To this day, these business relationships remain difficult to establish and manage.

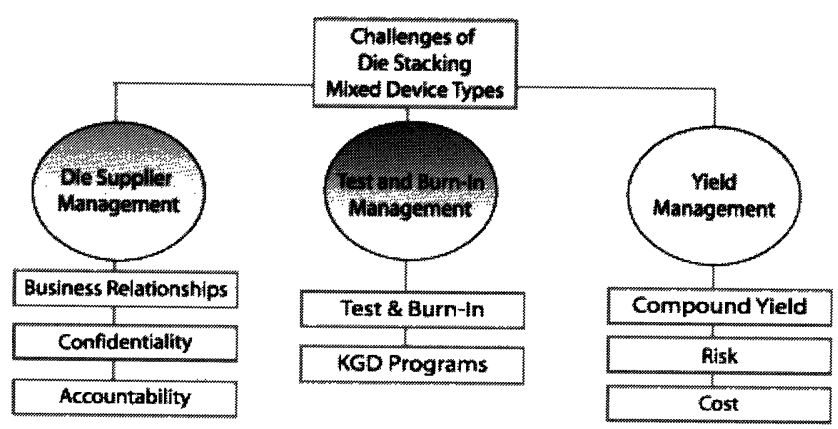

Fig. 1 Key challenges associated with die stacking mixed devices 
When several silicon vendors provide chips for a multi-chip package, it can be difficult to decide who is responsible for overall component quality. Also, many silicon vendors consider their final test vectors proprietary and confidential, and they may be unwilling to make them available.

Test and Burn-in Management: Placing multiple chips into a single integrated package can create several problems. Some devices in the multi-chip solution may require full functional test and possibly burn-in after final package assembly, and it may not be desirable to submit one device in the stack to the mandatory burnin conditions of another device. The packager must rely on the silicon suppliers' "known good die" (KGD) programs to assure the ultimate quality and yield of their multi-chip component. KGD programs are fairly common today, but there are costs associated with these programs due to tighter defect margins, longer test times on more expensive test equipment, and higher risk for potential compound yield losses at the module assembly level. In addition, KGD programs frequently do not apply to leading edge chips.

Yield Management: Even with KGD and other testing methods, complete testing of die before packaging remains very difficult with today's solutions. Yield is an important consideration with multi-chip packages, as costs can increase dramatically as a result of compounding yields as more chips are placed in a single package. The risk for implementing any high value chip into these packages remains significant-if the lower value chips are found damaged or defective following assembly into the chip stack, the higher value chip has to be discarded.

For these and a number of additional technical and logistical considerations, the industry is exploring new package stacking technologies that provide the desired level of integration while also addressing the challenges associated with die stacking mixed device types.

\section{Packaging Stacking in Wireless Handsets}

In a typical wireless handset, the baseband processor and the memory components and interface bus require the highest level of $\mathrm{I} / \mathrm{O}$ and wiring density. Providing a CSP platform to stack memory components on the processor not only saves space, but also allows for the integration of the memory bus in the stack, thereby reducing the wiring density and cost in the motherboard

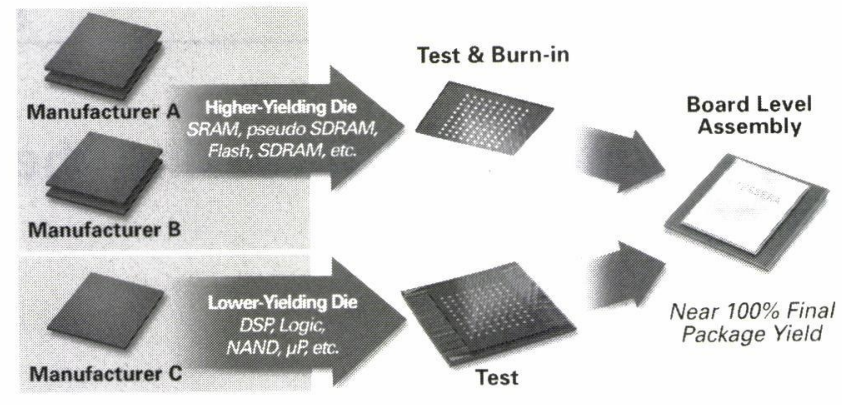

Fig. 2 Packaging and testing devices before stacking provides testing and sourcing flexibility and ensures essentially $100 \%$ final package yield

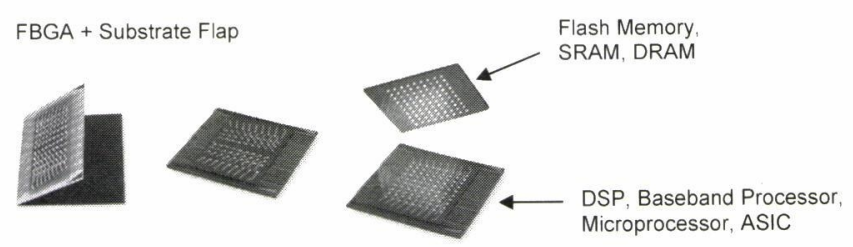

Fig. 3 The $\mu Z^{T M}$ Fold-Over logic+memory stacked package consists of a fine pitch BGA (FBGA) package with a foldable flap that incorporates a standard memory footprint

itself. Trying to achieve this level of integration and density with die stack technologies can be challenging in the substrate fabrication and assembly processes. But even when these technical challenges are overcome, the compound yield, test and logistics challenges often prevent die stack technologies from being cost-effective.

A stackable CSP can address this integration challenge by allowing different memory components to be stacked on a logic component yet still use the current footprint, pin-out standards and existing industry infrastructure ${ }^{4)}$. Logic components can be produced, tested, marketed, and sourced separately from the memory component, while still allowing a single CSP footprint (Figure 2). This approach also effectively addresses the assembly, business and logistics integration challenges many silicon suppliers face today with stacked die technologies.

Figure 3 illustrates Tessera's stacked CSP designed for stacking logic and memory chips.

\section{Implementation Example}

The package starts with a two-metal layer substrate (Figure 4). The $\mu Z^{\mathrm{TM}}$ Fold-Over technology package represents a significant new area of opportunity for high-density flex circuitry and $\mathrm{TAB}$ tape providers. The industry is seeking to eliminate the nickel and 


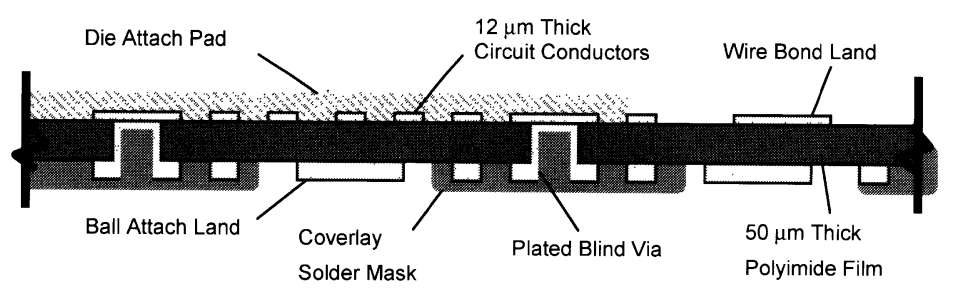

Fig. 4 Two-metal layer tape, an example is shown in cross-section here, is available from several suppliers, including Compass, Hitachi Cable, Shindo, Ube and LGE

gold plating under solder ball land pads due to intermetallic issues that limit board-level solder joint reliability. Interposer providers that can offer cost-effective high-density flexible substrates with selective nickel/ gold plating for bond fingers and organic solderable preservatives (OSP) for ball pads can have a significant competitive advantage.

The high I/O device is bonded to the two-metal substrate, and conventional wire bonding and overmolding processes follow. The substrate is then folded over and adhered to the mold cap, creating a memory footprint for surface mounting a pre-tested and burned-in memory component on top of the logic device. The base logic and top memory footprints can be designed to meet existing logic pin-out and footprint standards, allowing the logic component to accept "off the shelf" memory devices, including stacked or combination memory components. Figure 5 provides a cross-sectional view of $\mu \mathrm{Z}^{\mathrm{TM}}$ Fold-Over technology.

The folding step is the only process requiring new equipment for a back-end CSP assembly line. The folding of flex circuit assemblies has been done for decades in the medical, military and consumer industries.

The package stacking process can be achieved at board-level in standard SMT lines allowing one pass through a reflow oven for all components, resulting in little or minimal impact on standard board assembly processing (Figure 6).

By providing a standardized memory interface between the baseband and memory components, this ap-

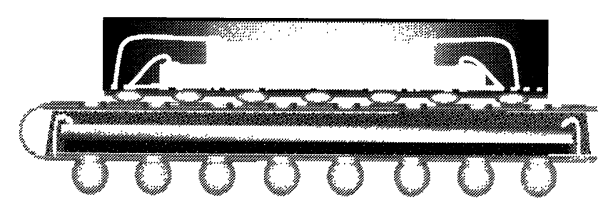

Fig. 5 The $\mu \mathrm{Z}^{\mathrm{TM}}$ Fold-Over Package can be designed to meet existing pin-out and footprint standards

proach allows handset manufactures to source memory and logic devices separately from various, even competing vendors. Also, the fold-over "flap" makes it possible for the lower yielding chip to be pre-packaged and tested prior to the attachment of the higher yielding memory devices. Conversely, the memory devices can be tested and burned-in, if required, independently of the baseband chip. The final stacking operation can be carried out by the semiconductor manufacturer after both packages have been assembled or by the board assembler just prior to or during board assembly. This provides a significant level of integration in a package approximately the size of the baseband chip itself.

\section{Conclusion}

The wireless electronics industry has been driving greater functionality in smaller form factors ${ }^{5)}$. Die stacking will continue to be an effective solution for integrating similar device types, such as high-yielding memory chips.

As the industry drives toward mixed device integration, alternative approaches such as package stacking
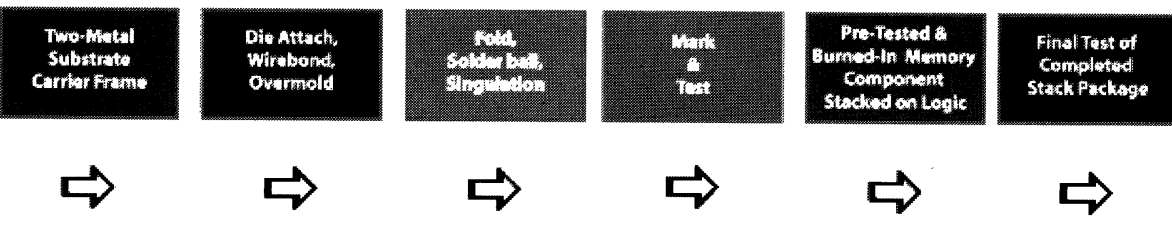

Package Assembly Process

Fig. $6 \mu \mathrm{Z}^{\mathrm{TM}}$ Fold-Over Package Assembly Process 
will be critical for achieving higher levels of integration at acceptable cost. Emerging packaging stacking approaches, such as the logic + memory technology described here, are designed to provide multi-vendor and die sourcing flexibility, while also driving down overall system cost by addressing the business and logistics issues associated with stacking mixed devices in a multi-chip package. The end result is more fully featured electronic products that meet the wireless industry's aggressive size, cost and time-to-market roadmaps.

(2004.5.8-受理)

\section{References}

1) G. Raskin: "Integration Challenges for Wireless IC Handset Makers", 3D Packaging Symposium, July 15, 2003

2) J. Vardaman: "Stacked CSPs: Market and Technology Developments", $10^{\text {th }}$ Annual International KGD Packaging
\& Test Workshop, September 8-10, 2003

3) C. E. Bauer and J. Riley: "Multichip Packaging: Business and Logistical Issues", Advanced Packaging, p. 29, January 2003

4) L. Smith: "Applications and Advances in Chip Scale Packaging Stacking", IMAPS Advanced Technology Workshop on Advanced 3D Packaging, March 12, 2003

5) S. Greathouse: “3D Stacked Package Technology, Facing Tomorrow's Needs Today", 3D Packaging Symposium, July 15, 2003

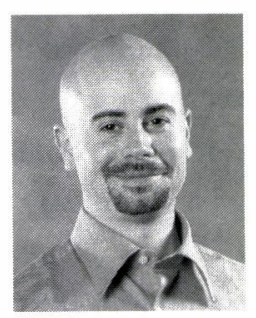

Craig MITCHELL

Craig Mitchell, Tessera's vice president of marketing, has been with Tessera for over ten years and has held numerous management positions, including vice president and director of memory business, director of product and technical marketing, and director of field applications. $\mathrm{He}$ is named as co-inventor on 21 patents. Mitchell received a bachelor's degree in electrical engineering from Manhattan College in New York City. 